\title{
Changes in the Protein and Cyanide Contents of Pupuru as Affected by Duration of Fermentation of Cassava with Species of Rhizopus
}

\author{
Johnson Akinwumi Adejuyitan*, Ezekiel Tejumola Otunola, Islamiyat Folashade Bolarinwa and Bosede Folake Olanipekun
}

Department of Food Science and Engineering, Ladoke Akintola University of Technology, P.M.B.4000, Ogbomoso, Nigeria

"Correspondence to:

Johnson Akinwumi Adejuyitan

Department of Food Science and Engineering

Ladoke Akintola University of Technology

P.M.B.4000, Ogbomoso, Nigeria

E-mail: jadejuyitan@lautech.edu.ng

Received: December 01, 2016

Accepted: January 19, 2017

Published: January 23, 2017

Citation: Adejuyitan JA, Otunola ET, Bolarinwa IF, Olanipekun BF. 2017. Changes in the Protein and Cyanide Contents of Pupuru as Affected by Duration of Fermentation of Cassava with Species of Rhizopus. J Food Chem Nanotechnol 3(1): 19-23.

Copyright: (C) 2017 Adejuyitan et al. This is an Open Access article distributed under the terms of the Creative Commons Attribution 4.0 International License (CC-BY) (http:// creativecommons.org/licenses/by/4.0/) which permits commercial use, including reproduction, adaptation, and distribution of the article provided the original author and source are credited.

Published by United Scientific Group

\begin{abstract}
Fermentation with micro-fungi has been identified as an inexpensive tool for increasing the protein level of substrates in a solid media fermentation technique. This study investigated influence of cassava fermentation using selected species of Rhizopus ( $R$. oryzae, $R$. oligosporous and $R$. nigricans) in an attempt to enhance its nutritional value. Three cassava varieties namely 'odongbo', 'okoiyawo' and 'arubielu' used were peeled and grated and subsequently inoculated with single culture and combinations from the three species of Rbizopus at different fermentation days (2, 4 and 6 days). The fermented mash samples were subsequently processed into pupuru. All the samples were analysed for their protein and cyanide contents. With single species of Rhizopus fermentation, protein content of 'pupuru' ranged from 10.20-11.28\%. Protein content of 7.94$11.24 \%$ was obtained with combination of the organisms. There was a significant reduction in the cyanide level which ranged from $0.42-0.80 \mathrm{mgHCN} / \mathrm{kg}$.
\end{abstract}

\section{Keywords}

Cassava, Rhizopus, Fermentation, Pupuru, Protein, Cyanoglucosides

\section{Introduction}

Cassava (Manihot esculenta Crantz), serves as an important food crop due to its efficient production of food energy, tolerances to extreme stress conditions, availability suitable for present farming and food system in Africa. It is a starchy root crop and a major source of food security in Africa because of its ability to grow in low-quality soil, its resistance to drought and disease, and its flexible cultivation cycle [1-3]. Nigeria is the world's leading cassava producer, with about 21 percent share in the global market [3,4].

Cassava is the most widely consumed food staple in Nigeria $[3,5]$ and the main traditional cassava food products in Nigeria are gari, lafun, fufu and pupuru. A cassava staple is consumed by more than 130 million people in Nigeria [6], however it has high levels of carbohydrate but lacks essential nutrients such as protein, fat, vitamins and minerals needed in adequate supply by the body.

The two important methods of increasing the protein content of fermented cassava products have been identified to consist of adding protein to the deficient food from external sources in such a way as not to alter significantly the organoleptic qualities of the food. Consequently, several studies have examined the fortification of cassava meal with vegetable protein like soybean flour, groundnut flour and sesame flour in varying proportions in which for instance the biological value of gari has been found to be raised from 47 to 68 with this blend $[7,8]$. The second method is through controlled fermentation where the micro- 
flora could be made in large numbers in the mash by solid state fermentation with the use of filamentous microfungi [9].

Fungal fermentation has been identified as an inexpensive tool for increasing the protein level of substrates in a solid media fermentation technique [10]. Solid-state fermentation (SSF) involves the growth of microorganisms on predominantly insoluble substrates, with low moisture content (no free liquid) [11]. SSF is a low energy technique that has played vital role in the use of microorganisms to produce beneficial and commercially viable products. It has been successfully used in the transformation of agricultural wastes such as yam peels [12] and has been exploited for the production of feed from carbohydrate substrates (wastes), which has great potential as animal and livestock feed [13]. The possibility of using fungal strains to upgrade the protein content of cassava products by solid state fermentation has been investigated by several authors $[9,10,14,15]$. This study is therefore aimed at evaluating the effect of fermentation of cassava variety with selected Rbizopus species at different fermentation time on the protein and cyanide contents of pupuru.

\section{Materials and Method}

\section{Materials}

Three varieties of cassava namely Oko iyawo, Odongbo and Arubielu variety were collected from the Research and Teaching farm of Ladoke Akintola University of Technology, Ogbomoso, Oyo State, Nigeria while the Rhizopus species ( $R$. oryzae, $R$. oligosporous and $R$. nigricans) that were used were obtained from the Microbiology Unit of Department Pure and Applied Biology, Ladoke Akintola University of Technology, Ogbomoso. The chemicals that were used were of analytical grade manufactured by May and Baker Ltd.

\section{Sub culturing of the species of Rhizopus}

Each species of the Rhizopus was sub-cultured by transferring a bit of each typical colony from its edge onto a sterile Potato dextrose agar (PDA) and incubated for 3-5 days [16]. Following incubation, plates of the organisms were kept for subsequent inoculation into the cassava mash.

\section{Preparation of cassava mash for inoculation with species of Rbizopus}

The method of Oboh and Elusiyan [9] was adopted with little modifications. Each of the varieties of cassava was peeled, washed, grated and pressed after which $1 \mathrm{~kg}$ of the mash was spread on a tray. About $0.5 \mathrm{~g}$ freshly sub-cultured pure strains of $R$. oryzae, $R$. oligosporous or $R$. nigricans each, their combinations and the consortium of the microorganisms in $730 \mathrm{ml}$ nutrient solution [containing urea $(80.0 \mathrm{~g})$, $\mathrm{MgSO}_{4} .2 \mathrm{H}_{2} \mathrm{O}(70.0 \mathrm{~g}), \mathrm{KH}_{2} \mathrm{PO}_{4}(13 \mathrm{~g})$ and citric acid $\left.(20 \mathrm{~g})\right]$ was carefully added to the solid matrix and thoroughly mixed. The mash was allowed to ferment for two, four and six days. The control experiment was also carried out on the cassava mash fermented without the Rhizopus species. After the fermentation, the mash samples were processed into pupuru as indicated below (Figure 1).

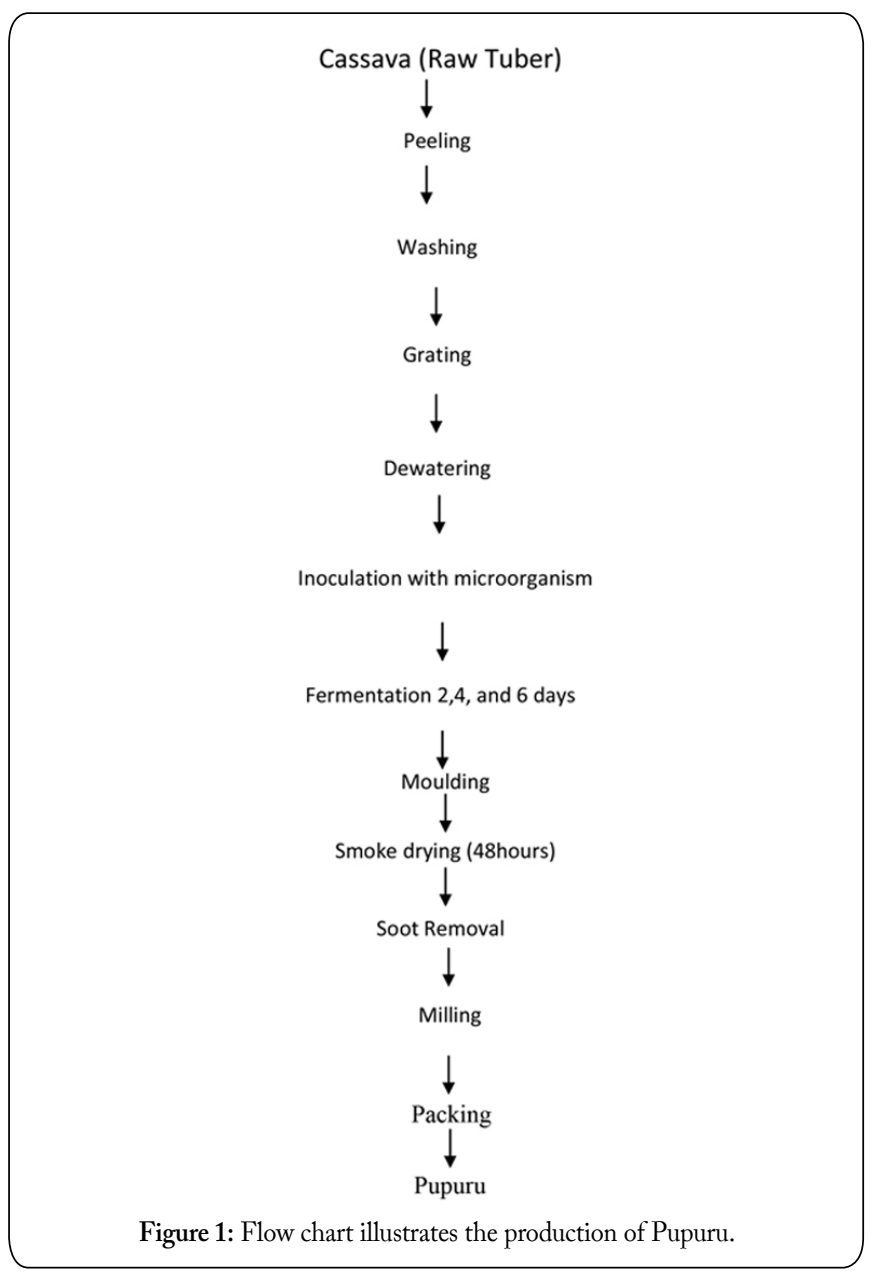

\section{Pupuru processing}

The fermented mash was made into a ball shape and smoked until a light dark-brownish colour was obtained. The smoked ball was then pulverized and sieved followed by toasting and milling into flour [17]. The resultant product known as pupuru was packaged and kept for further analyses.

\section{Chemical analyses}

Determination of protein content

This was determined according to the procedure of Official Methods of Analysis of AOAC International, $18^{\text {th }}$ edition [18].

\section{Determination of cyanide content}

The method of Nwokoro et al. [19] as modified by Orjiekwe et al. [20] was adopted. Residual cyanogenic glucosides were extracted from the pupuru samples by mixing about $10 \mathrm{~g}$ of the sample with $50 \mathrm{ml}$ of water in corked conical flask and was allowed to stand for $24 \mathrm{hrs}$. The mixture was later filtered to obtain the extract cyanogenic glucosides. This was followed by determination of the free cyanide which involves preparation of varying concentrations of standard $\mathrm{KCN}$ solution from stock solution. The KCN solution was sealed with Picrate paper after being acidified with $20 \% \mathrm{HCl}$ and kept at $80{ }^{\circ} \mathrm{C}$ for 10 mins. The picrate paper was removed and kept at room temperature for $24 \mathrm{hr}$ which later turned red. The picrate paper was then rinsed in 50\% ethanol solution after which the absorbance was read using spectrometer and was 
plotted against the graph after which the amount of cyanide was calculated.

\section{Results and Discussions}

\section{Protein content of pupuru as affected by fermentation with species of Rhizopus}

The results of protein content of pupuru flour samples are presented in Tables 1-3. The protein content of pupuru flour samples obtained from fermentation with single species of Rbizopus ranged between 7.94 and $10.32 \%$ (Table 1 ) with Odogbo variety. Fermentation with $R$. oryzae for four days gave the highest value of protein content (10.32\%). With Oko-iyawo, the protein content obtained ranged between 8.41 and $10.42 \%$ with highest value obtained from fermentation with $R$. nigricans for six days. The lowest value (8.41\%) was obtained with fermentation with $R$. oligosporous for six days. With fermentation using single species of Rbizopus, significant changes were observed in the protein content of pupuru flour samples across the three varieties of cassava. As fermentation days progressed there was increase in protein content. In Odongbo cassava variety, fermentation with $R$. oryzae in the $4^{\text {th }}$ day of fermentation produced pupuru flour samples with highest protein content of $10.32 \%$ but later decreased to $10.21 \%$ in the $6^{\text {th }}$ day of the fermentation. Pupuru flour samples obtained from Oko-iyawo cassava variety produced protein content of $10.42 \%$ with fermentation using $R$. nigricans with 6 days fermentation which is the highest value among the samples. Lowest value of protein (8.41\%) was obtained with fermentation using $R$. oligosporous with 6 days fermentation. Samples of pupuru flour prepared from Arubielu cassava variety indicated the highest protein content of $10.24 \%$ with

Table 1: Protein content (\%) of pupuru as influenced by length of fermentation with single of species of Rhizopus.

\begin{tabular}{|l|l|l|l|}
\hline \multicolumn{5}{|c|}{ Cassava Varieties } \\
\hline Pupuru Samples & Odongbo & Oko-iyawo & Arubielu \\
\hline SP1 & $10.06^{\mathrm{b}}$ & $10.21^{\mathrm{b}}$ & $7.24^{\mathrm{g}}$ \\
\hline SP2 & $10.32^{\mathrm{a}}$ & $9.68^{\mathrm{c}}$ & $9.16^{\mathrm{b}}$ \\
\hline SP3 & $10.21^{\mathrm{a}}$ & $9.54^{\mathrm{f}}$ & $10.24^{\mathrm{a}}$ \\
\hline SP4 & $8.24^{\mathrm{e}}$ & $9.82^{\mathrm{d}}$ & $8.24^{\mathrm{e}}$ \\
\hline SP5 & $7.94^{\mathrm{d}}$ & $9.52^{\mathrm{f}}$ & $8.52^{\mathrm{c}}$ \\
\hline SP6 & $10.14^{\mathrm{a}}$ & $8.41^{\mathrm{g}}$ & $8.93^{\mathrm{c}}$ \\
\hline SP7 & $10.24^{\mathrm{a}}$ & $9.54^{\mathrm{f}}$ & $7.54^{\mathrm{e}}$ \\
\hline SP8 & $9.25^{\mathrm{b}}$ & $9.62^{\mathrm{e}}$ & $7.36^{\mathrm{f}}$ \\
\hline SP9 & $9.36^{\mathrm{b}}$ & $10.42^{\mathrm{a}}$ & $7.25^{\mathrm{h}}$ \\
\hline NP & $3.33^{\mathrm{e}}$ & $3.41^{\mathrm{h}}$ & $3.25^{\mathrm{i}}$ \\
\hline
\end{tabular}

Values are means of triplicate determinations.

Means in the same column bearing different superscript are significantly different $(\mathrm{p}<0.05)$.

SP1- Fermentation with $R$. oryzae for 2 days.

SP2 - Fermentation with $R$. oryzae for 4 days.

SP3 - Fermentation with $R$. oryzae for 6 days.

SP4 - Fermentation with $R$. oligosporous for 2 days.

SP5 - Fermentation with $R$. oligosporous for 4 days.

SP6 - Fermentation with $R$. oligosporous for 6 days.

SP7 - Fermentation with $R$. nigricans for 2 days.

SP8 - Fermentation with $R$. nigricans for 4 days.

SP9 - Fermentation with $R$. nigricans for 6 days.

NP - Control, Natural Fermentation (without inoculation fermented for three days). fermentation using $R$. oryzae for 6 days. Moreover, among the samples from the Arubielu cassava variety, protein content was found to increase significantly as fermentation days increased though noticeable decrease was observed at 6 days fermentation with $R$. nigricans.

Using combination of species of Rhizopus as indicated in Table 2 for fermentation, pupuru flour samples indicated higher amount of protein content particularly with samples from Oko-iyawo cassava variety (10.24-11.94\%). The values were higher than the ones obtained in samples obtained from fermentation with single species of Rbizopus. Similarly significant changes were observed among the samples with combination of the species of Rhizopus for fermentation.

Table 2: Protein content (\%) of pupuru as influenced by length of
fermentation with combination of species of Rhizopus.
\begin{tabular}{|l|l|l|l|}
\hline \multicolumn{4}{|c|}{ Cassava Varieties } \\
\hline Pupuru Samples & Odongbo $^{\mathrm{O}}$ Oko-iyawo & Arubielu \\
\hline MP1 & $10.92^{\mathrm{a}}$ & $11.92^{\mathrm{a}}$ & $8.24^{\mathrm{g}}$ \\
\hline MP2 & $10.44^{\mathrm{e}}$ & $11.94^{\mathrm{a}}$ & $8.42^{\mathrm{h}}$ \\
\hline MP3 & $9.44^{\mathrm{g}}$ & $10.94^{\mathrm{d}}$ & $9.20^{\mathrm{f}}$ \\
\hline MP4 & $10.24^{\mathrm{f}}$ & $10.94^{\mathrm{d}}$ & $9.00^{\mathrm{g}}$ \\
\hline MP5 & $10.64^{\mathrm{d}}$ & $10.84 \mathrm{e}$ & $9.35^{\mathrm{e}}$ \\
\hline MP6 & $9.84^{\mathrm{g}}$ & $11.00^{\mathrm{d}}$ & $9.45^{\mathrm{d}}$ \\
\hline MP7 & $10.74^{\mathrm{c}}$ & $11.24^{\mathrm{b}}$ & $10.42^{\mathrm{c}}$ \\
\hline MP8 & $10.82^{\mathrm{b}}$ & $11.15^{\mathrm{c}}$ & $10.52^{\mathrm{b}}$ \\
\hline MP9 & $10.84^{\mathrm{b}}$ & $10.24^{\mathrm{e}}$ & $10.62^{\mathrm{a}}$ \\
\hline NP & $3.30^{\mathrm{h}}$ & $3.41^{\mathrm{f}}$ & $3.24^{\mathrm{j}}$ \\
\hline
\end{tabular}

Vales are means of triplicate determinations.

Means in the same column bearing different superscript are significantly different $(\mathrm{p}<0.05)$.

MP1- Fermentation with combination of $R$. oryzae and $R$. oligosporous for 2 days. MP2 - Fermentation with combination of $R$. oryzae and $R$. oligosporous for 4 days. MP3 - Fermentation with combination of $R$. oryzae and $R$. oligosporous for 6 days. MP4 - Fermentation with combination of $R$. oryzae and $R$. nigricans for 2 days. MP5 - Fermentation with combination of $R$. oryzae and $R$. nigricans for 4 days. MP6 - Fermentation with combination of $R$. oryzae and $R$. nigricans for 6 days. MP7- Fermentation with combination of $R$. oligosporous and $R$. nigricans for 2 days. MP8 - Fermentation with combination of combination of $R$. oligosporous and $R$. nigricans for 4 days.

MP9 - Fermentation with combination of $R$. oligosporous and $R$. nigricans for 6 days. NP - Control, Natural Fermentation (without inoculation fermented for three days).

Using the consortium of the three species of Rhizopus for fermentation (Table 3) produced pupuru flour sample with highest protein content of $11.05 \%$ with fermentation using $R$. oryzae fermented for 2 days in Arubielu cassava variety. Similarly significant changes were recorded in the protein

Table 3: Protein content (\%) of pupuru as in influenced by length of fermentation with consortium of species of Rhizopus.

\begin{tabular}{|l|l|l|l|}
\hline \multicolumn{5}{|c|}{ Cassava Varieties } \\
\hline Pupuru Samples & Odongbo & Oko-iyawo & Arubielu \\
\hline CP1 & $11.02^{\mathrm{a}}$ & $10.24^{\mathrm{a}}$ & $11.05^{\mathrm{a}}$ \\
\hline CP2 & $10.42^{\mathrm{b}}$ & $9.14^{\mathrm{b}}$ & $10.50^{\mathrm{b}}$ \\
\hline CP3 & $10.33^{\mathrm{b}}$ & $10.24^{\mathrm{a}}$ & $9.42^{\mathrm{c}}$ \\
\hline NP & $3.33^{\mathrm{c}}$ & $3.41^{\mathrm{c}}$ & $3.25^{\mathrm{d}}$ \\
\hline
\end{tabular}

Values are means of triplicate determinations.

Means in the same column bearing different superscript are significantly different $(\mathrm{p}<0.05)$

$\mathrm{CP}$ 1: Fermentation with consortium of the three species for 2 days.

$\mathrm{CP} 2$ : Fermentation with consortium of the three species for 4 days.

CP3: Fermentation with consortium of the three species 6 days.

NP: Control Sample by natural fermentation. 
content across the cassava varieties as fermentation days progressed. Likewise control samples from all the treatments were lower in protein content than the samples obtained from fermentation with species of Rhizopus.

According to Akindahunsi et al. [21] and Okafor N. [22], the increase in protein may be due to metabolic activities of the microfungi as a result of extracellular enzymes during the fermentation of cassava mash which according to Reed G. [23] has been enhanced by the presence of ammonia as a nitrogenous base of the medium. This has resulted to the multiplication of the fungi in form of single cell protein. This may also be as a result of the urea added as the basal medium for the organisms.

Changes in protein quality and quantity during different fermentation techniques have also been studied. Crude protein was enhanced to $2.56 \%$ during fufu production and to $3.68 \%$ in Pukuru (Pupuru) but was reduced to $1.43 \%$ in gari and $1.14 \%$ in Kpokpo gari compared with $2.04 \%$ in cassava chips [24]. Although there was reduction in protein content in the latter products, there was general improvement in feed intake and growth rate of rats fed on diets containing fermented products. During fufu production, a $20 \%$ reduction in protein content was observed. At the end of $72 \mathrm{~h}$, value dropped from $1.5 \%$ to $0.9 \%$, subsequently increasing to $1.2 \%$, which might be attributed to increased biomass production [25].

\section{Cyanide content of pupuru as affected by fermentation with species of Rhizopus}

The results of cyanide content of pupuru as influenced by fermentation with species of Rhizopus are presented in Figures 2-4. With fermentation using single species of Rhizopus, significant changes were observed as fermentation days progressed across the three varieties of cassava with cyanide content ranged from $0.52-0.75 \mathrm{mgHCN} / \mathrm{kg}$ (Odongbo cassava variety); $0.32-0.73 \mathrm{mgHCN} / \mathrm{kg}$ (Oko-iyawo cassava variety) and $0.25-0.72 \mathrm{mgHCN} / \mathrm{kg}$ (Arubielu cassava variety).

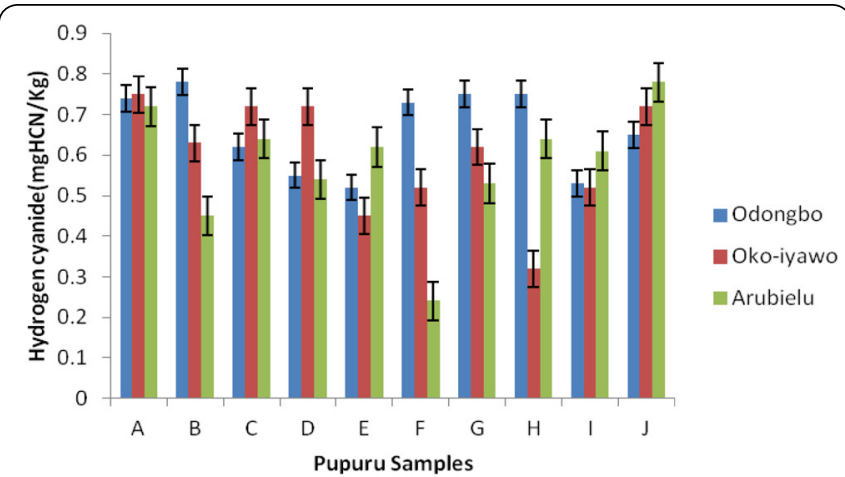

Figure 2: Hydrogen cyanide of Pupuru as influenced by fermentation with single species of Rhizopus with different cassava varieties.

$\mathrm{A}=$ Control

$\mathrm{B}=$ Fermentation with $R$. oryzae for 2 days

$\mathrm{C}=$ Fermentation with $R$. oryzae and for 4 days

$\mathrm{D}=$ Fermentation with $R$. oryzae for 6 days

$\mathrm{E}=$ Fermentation with $R$. oligosporous for 2 days

$\mathrm{F}=$ Fermentation with $R$. oligosporous for 4 days

$\mathrm{G}=$ Fermentation with $R$. oligosporous for 6 days

$\mathrm{H}=$ Fermentation with $R$. nigricans for 2 days

$\mathrm{I}=$ Fermentation with $R$. nigricans for 4 days

$\mathrm{J}=$ Fermentation with $R$. nigricans for 6 days

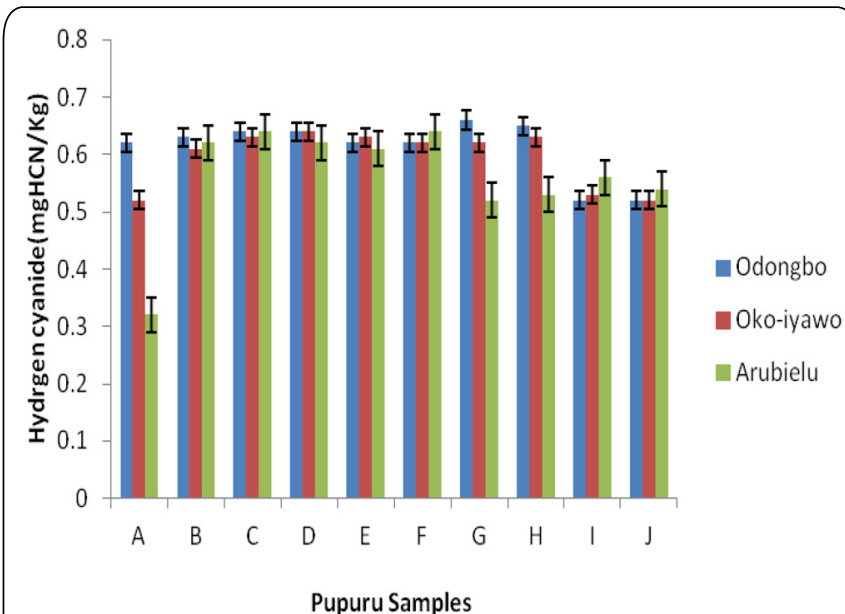

Figure 3: Hydrogen cyanide of Pupuru as influenced by fermentation with combination of species of Rhizopus with different cassava varieties.

A -Sample from fermentation with combination of $R$. oryzae and $R$. oligosporous for 2 days

B -Sample from fermentation with combination of $R$. oryzae and $R$. oligosporous for 4 days

C -Sample from fermentation with combination of $R$. oryzae and $R$. oligosporous for 6 days

D -Sample from fermentation with combination of $R$. oryzae and $R$. nigricans for 2 days

E - Sample from fermentation with combination of $R$. oryzae and $R$. nigricans for 4 days

F - Sample from fermentation with combination of $R$. oryzae and $R$. nigricans for 6 days

$\mathrm{G}$ - Sample from fermentation with combination of $R$. oligosporous and $R$. nigricans for 2 days

$\mathrm{H}$ - Sample from fermentation with combination of $R$. oligosporous and $R$. nigricans for 4 days

I -Sample from fermentation with combination of $R$. oligosporous and $R$. nigricans for 6 days

J - Control, Natural Fermentation

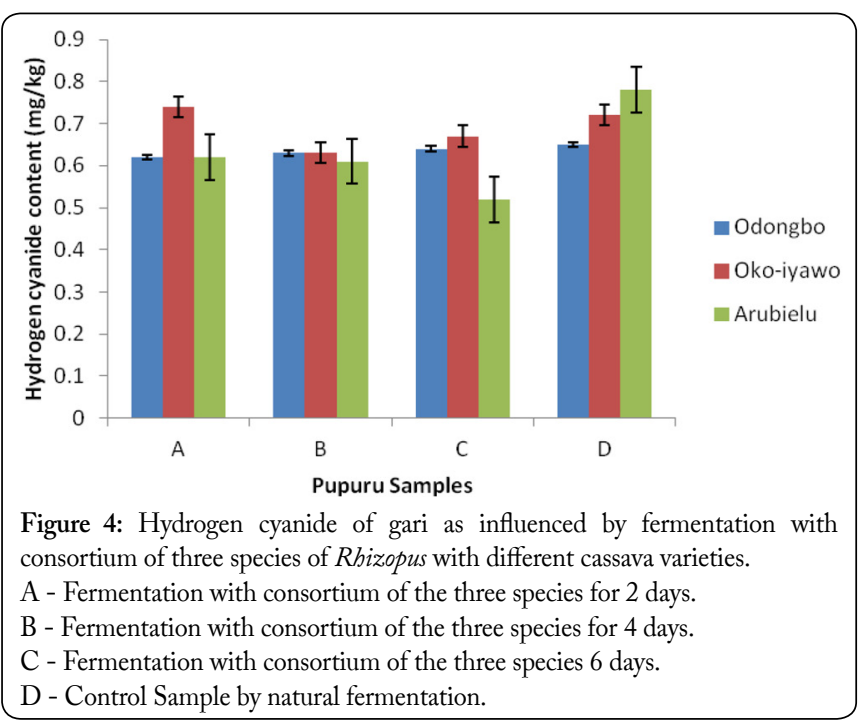

Pupuru samples obtained from fermentation using combination of species of Rbizopus indicated the value of cyanide to range between $0.56-0.64 \mathrm{mgHCN} / \mathrm{kg}$ (Odongbo); $0.52-0.62 \mathrm{mgHCN} / \mathrm{kg}$ (Oko-iyawo cassava variety) and 0.25$0.72 \mathrm{mgHCN} / \mathrm{kg}$ (Arubielu cassava variety). Pupuru samples obtained from fermentation with consortium of species of Rhizopus indicated the values of cyanide to range between 0.61 - $0.62 \mathrm{mgHCN} / \mathrm{kg}$ (Odongbo cassava variety); 0.60- 
$0.72 \mathrm{mgHCN} / \mathrm{kg}$ (Oko-iyawo cassava variety) and 0.53-0.60 $\mathrm{mgHCN} / \mathrm{kg}$ (Arubielu).

Fermentation with species of Rhizopus reduced the cyanide content to a safe level in all the samples of Pupuru. A value of $2-3 \mathrm{mg} / 100 \mathrm{~g}$ has been regarded as acceptable level of cyanide in gari [26]. The cyanide levels of the pupuru sample falls within the recommended acceptable and safe levels, however studies have shown that long exposure to small doses of cyanide could be fatal and result in the increased blood cyanide levels with symptoms like headache, dizziness, nausea, vomiting, paralysis, nerve lesions and miscarriages $[20,27,28]$.

\section{Conclusion}

Protein content of pupuru samples obtained from fermentation of cassava with combinations of the species of Rhizopus was observed to be higher than the samples obtained from fermentation with single species of the organisms. The protein content of the control sample obtained by natural fermentation was much lower than the samples obtained from fermentation with the species of Rhizopus. The cyanogenic glucosides levels in the pupuru samples ranged from 0.42 to $0.80 \mathrm{mgHCN} / \mathrm{Kg}$ which is relatively very safe and within the acceptable limit of $10 \mathrm{mg} \mathrm{HCN}$ equivalent/ $\mathrm{Kg}$ body weight recommended by FAO.

\section{References}

1. Sanni LO, Onadipe OO, Ilona P, Mussagy MD, Abass A, et al. 2009. Successes and challenges of cassava enterprises in West Africa: a case study of Nigeria, Benin and Sierra Leone. Ibadan, Nigeria: International institute of tropical agriculture.

2. Meriddian Institute. 2013. Cassava value chain overview. Innovation for agricultural value chains in Africa. Applying science and technology to enhance, cassava, dairy and maize value chains.

3. McNulty E, Oparinde A. 2015. Cassava value chain in Nigeria: a review of the literature to inform the integration of vitamin a cassava.

4. FAO (Food and Agriculture Organization of the United Nations). 2011. FAQ: Contract farming resource centre, food and agriculture organization of the United Nations (FAO).

5. Nweke FI, Dunstan SC, Spencer DSC, Lyman JK. 2002. The cassava transformation. Michigan State University Press, MI, USA.

6. SciDev.Net. 2016. A step towards a better nutrition for African children. In: Bringing science and development together through news and analysis.

7. Obadina AO, Oyewole OB, Sanni LO, Abiola, SS. 2006. Fungal enrichment of cassava peels proteins. Afr J Biotechnol 5(3): 302-304. doi: 10.5897/AJB05.360

8. Eke UB, Owalude SO, Usman LA. 2008. Enrichment of a cassava meal (gari) with soyabean protein extract. Adv in Nat Appl Sci 2(2): 60-62.

9. Oboh G, Elusiyan CA. 2007. Changes in the nutrient and anti-nutrient content of micro- fungi fermented cassava flour produced from a lowand medium-cyanide variety of cassava tubers. Afr J Biotechnol 6(18): 2150-2157. doi: 10.5897/AJB2007.000-2336

10. Akintomide MJ, Antai SP. 2012. Protein enrichment of Irish potato
(Solanum tuberosium) through solid substrate fermentation by Saccharomyces cerevisiae and Aspergillus niger. IOSR-AJESTFT 1(5): 1519. doi: $10.9790 / 2402-0151519$

11. Anupuma, Ravindra P.2001. Studies on production of single cell protein by Aspergillus niger in solid state fermentation of rice bran. Braz Arch Biol Technol 44(1): 79-88. doi: 10.1590/S1516-89132001000100011

12. Aderiye BJ, Ogunjobi AA. 1998. Fermentation of yam: microbiology and sensory evaluation of cooked fermented yam tissues. Plant Foods Hum Nutr 52(1): 49-54. doi: 10.1023/A:1008023603890

13. Ravinder R, Rao LV, Ravindra P. 2003. Studies on Aspergillus oryzae mutants for the production of single cell protein from deoiled rice bran. Food Technol Biotechnol 41(3): 243-246.

14. Oboh G, Akindahunsi AA, Oshodi AA. 2002. Nutrient and antinutrient content of Aspergillus niger fermented cassava products (flour and gari). J Food Compost Anal 15(5): 617-622. doi: 10.1006/ jfca.2002.1065

15. Oboh G, Akindahunsi AA. 2003. Biochemical changes in cassava products (flour and gari) subjected to Saccharomyces cerevisae solid media fermentation. Food Chem 82(4): 599-602. doi: 10.1016/S03088146(03)00016-5

16. Baker FJ, Silverton RE, Pallister CJ. 2007. Baker and Silverton's Introduction to medical laboratory technology, $7^{\text {th }}$ edition, Edward Arnold, London, UK, pp 299-316.

17. Adejuyitan JA. 2015. Influence of fermentation with Rhizopus species on the Properties of selected cassava-based foods. Ph.D. Thesis, Ladoke Akintola University of Technology, Ogbomoso, Nigeria.

18. AOAC. 2005. Official methods of analysis of AOAC International, $18^{\text {th }}$ edition, Maryland, USA

19. Nwokoro O, Ogbonna JC, Ubani CS, Okpala GN, Ofodile OE. 2010. Determination of cyanide in Amanitia muscaria samples using alkaline picrate method. Pakistan Journal of Nutrition 9(2): 134-136. doi: 10.3923/pjn.2010.134.136

20. Orjiekwe CL, Solola A, Iyen E, Imade S. 2013. Determination of cyanogenic glucosides in cassava products sold in Okada, Edo State, Nigeria. African Journal of Food Science 7(12): 468-472. doi: 10.5897/ AJFS2013.1012

21. Akindahunsi AA, Oboh G, Oshodi AA. 1999. Effect of fermenting cassava with Rhizopus oryzae on the chemical composition of its flour and gari. Rivista Italiana Delle Sostanze Grasse 76: 437-440.

22. Okafor N. 1998. An International biosystem for the disposal of cassava waste peels. JMicrobiol Biotechnol 5: 165-169.

23. Reed G. 1981. Use of microbial cultures: yeast products. Food Technology 35: 89-94.

24. Longe OG. 1980. Effect of processing on the chemical composition and energy value of cassava. Nutr Rep Int 21(6): 819-829.

25. Steinkraus KH. 1989. Industrialization of indigenous fermented foods. Marcel Dekker, Inc., New York, USA, pp 439.

26. IITA. 1989. International Institute of Tropical Agriculture, Annual report, Ibadan, Nigeria, pp 129

27. Soto-Blanco B, Górniak SL, Kimura ET. 2001. Physiopathological effects of administration of chronic cyanide to growing goats - a model for ingestion cyanogenic plants ingestion. Vet Res Commun 25(5): 379389. doi: 10.1023/A:1010694710124

28. Rachinger J, Fellner FA, Stieglbauer K, Trankler J. 2002. MR changes after acute cyanide intoxication. AJNR Am J Neuroradiol 23: 1398-1401. 